\title{
The CRK2-CYC13 complex functions as an S-phase cyclin-dependent kinase to promote DNA replication in Trypanosoma brucei
}

Kyu Joon Lee and Ziyin Li

\begin{abstract}
Background: Faithful DNA replication is essential to maintain genomic stability in all living organisms, and the regulatory pathway for DNA replication initiation is conserved from yeast to humans. The evolutionarily ancient human parasite Trypanosoma brucei, however, lacks many of the conserved DNA replication factors and may employ unusual mechanisms for DNA replication. Neither the S-phase cyclin-dependent kinase (CDK) nor the regulatory pathway governing DNA replication has been previously identified in T. brucei.
\end{abstract}

Results: Here we report that CRK2 (Cdc2-related kinase 2) complexes with CYC13 (Cyclin13) and functions as an Sphase CDK to promote DNA replication in T. brucei. We further show that CRK2 phosphorylates Mcm3, a subunit of the Mcm2-7 sub-complex of the Cdc45-Mcm2-7-GINS complex, and demonstrate that Mcm3 phosphorylation by CRK2 facilitates interaction with Sld5, a subunit of the GINS sub-complex of the Cdc45-Mcm2-7-GINS complex.

Conclusions: These results identify the CRK2-CYC13 complex as an S-phase regulator in T. brucei and reveal its role in regulating DNA replication through promoting the assembly of the Cdc45-Mcm2-7-GINS complex.

Keywords: Trypanosoma brucei, Mcm3, Sld5, Cdc45-Mcm2-7-GINS complex, Cdc2-related kinase, DNA replication

\section{Background}

High fidelity DNA replication is crucial for maintaining genomic integrity in all living organisms. Eukaryotic organisms use a replication licensing system to ensure that the genome is replicated once, and only once, per cell cycle. In the $\mathrm{G} 1$ phase of the cell cycle, the origin recognition complex (ORC), which is composed of six closely related AAA-type ATPases named Orc1 to Orc6, occupies the replication origins and loads another AAA-type ATPase named Cdc6 onto the origins. Cdc6 further recruits Cdt1 and the Mcm2-7 complex onto the origins,

\footnotetext{
* Correspondence: Ziyin.Li@uth.tmc.edu

Department of Microbiology and Molecular Genetics, McGovern Medical School, University of Texas Health Science Center at Houston, Houston, TX 77030, USA
}

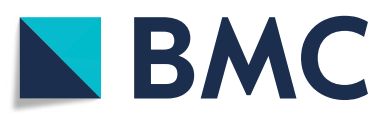

(C) The Author(s). 2021 Open Access This article is licensed under a Creative Commons Attribution 4.0 International License, which permits use, sharing, adaptation, distribution and reproduction in any medium or format, as long as you give appropriate credit to the original author(s) and the source, provide a link to the Creative Commons licence, and indicate if changes were made. The images or other third party material in this article are included in the article's Creative Commons licence, unless indicated otherwise in a credit line to the material. If material is not included in the article's Creative Commons licence and your intended use is not permitted by statutory regulation or exceeds the permitted use, you will need to obtain permission directly from the copyright holder. To view a copy of this licence, visit http://creativecommons.org/licenses/by/4.0/ The Creative Commons Public Domain Dedication waiver (http://creativecommons.org/publicdomain/zero/1.0/) applies to the data made available in this article, unless otherwise stated in a credit line to the data. thereby forming a pre-replicative complex $[1,2]$. Initiation of DNA replication requires the phosphorylation of multiple DNA replication factors by Dbf4-dependent kinase (DDK) or Cdk7 and S-phase cyclin-dependent kinase (CDK) [3]. The DDK/Cdk7 phosphorylates several subunits of the Mcm2-7 complex and promotes interaction with Cdc45 [4]. S-phase CDK phosphorylates replication factors Sld2 and Sld3 $[5,6]$ to facilitate their binding to Dpb11 [7]. Sld2, Dpb11, the GINS complex composed of Sld5, Psf1, Psf2, and Psf3, and the leadingstrand polymerase $\varepsilon(\mathrm{Pol} \varepsilon)$ form the pre-loading complex [8-11]. Sld3 interacts with Cdc45 and together they are recruited onto origins through interactions between Cdc45 and Mcm2-7 [4, 12, 13]. Interactions between Dpb11 and Sld3-Cdc45 help recruit the pre-loading 
complex onto origins [3]. Subsequently, Cdc6 (in budding yeast) or Cdt1 (in animals) is degraded, and Dpb11, Sld2, and Sld3 all dissociate from the replisome [3], leaving DNA polymerase and the CMG (Cdc45-Mcm2-7GINS) complex at the replication origins. The CMG complex functions as a replicative helicase to unwind the duplex DNA for the DNA polymerase to replicate DNA [14-17].

Trypanosoma brucei is an early branching protozoan parasite [18] causing human sleeping sickness in subSaharan Africa and possesses numerous unusual biological features that might be exploited as drug targets. The regulation of DNA replication in T. brucei, although poorly understood, appears to possess both evolutionarily conserved and trypanosome-specific features [19-21]. T. brucei expresses a highly divergent ORC complex, of which only five subunits have been identified [22-24], and a conserved CMG complex [22], but its genome does not encode close homologs of Cdc6, Cdt1, and DDK/Cdk7 [25]. It appears that T. brucei may employ a control mechanism for DNA replication that is distinct from that in yeast and animals.

The S-phase CDK, a crucial DNA replication regulator that helps recruitment of the pre-loading complex to the replication origins [3], and its associated cyclin partner have not been discovered in T. brucei. The genome of $T$. brucei encodes eleven Cdc2-related kinases (CRK1CRK4 and CRK6-CRK12) and eleven cyclins (CYC2CYC12) [26], but it remains unknown which CRK-CYC pair functions as an S-phase CDK-cyclin complex to promote DNA replication. Here, we discover CRK2 as an S-phase CDK to complex with a new cyclin, CYC13, to promote DNA replication and S-phase progression in T. brucei. We also uncover a mechanistic role of CRK2 in DNA replication by demonstrating that CRK2 phosphorylates the Mcm2-7 complex subunit Mcm3 to facilitate the interaction of $\mathrm{Mcm} 3$ with the GINS complex subunit Sld5. These findings reveal a novel mechanism for CRK2-mediated DNA replication and highlight the unusual biology of cell cycle regulation in this early divergent eukaryote.

\section{Results}

\section{CYC13 is the cyclin partner of CRK2 in T. brucei}

Hidden Markov Model (HMM) analysis identified 12 cyclin box-containing proteins in T. brucei shown in the superfamily HMM library and genome assignments server (http://supfam.org/SUPERFAMILY/cgi-bin/genome. cgi?sf $=47954$ \&listtype $=$ sf\&cgi_Tb=yes). Two of these proteins, encoded by Tb927.11.780 (or Tb11.03.0350) and Tb927.11.11500 (or Tb11.01.3350), have not been characterized previously. Tb927.11.11500 encodes a CDK-binding protein homologous to human CABLES protein [27], whereas the protein encoded by
Tb927.11.780 contains a cyclin box-like domain (a.a. 272-420; E-value: 2.61e-16) and thus was named CYC13. The cyclin-box domain of CYC13 has an overall $19 \%$ sequence identity and a similar structure to the cyclin-box domain of human cyclin A2 (Fig. 1a, b), as predicted by structural modeling using SWISS-MODEL [28]. Cyclin A2 in humans activates both Cdk2 and Cdk1 to regulate S-phase and mitosis, respectively [29]. Sequence analyses of all trypanosome cyclins, CYC2CYC13, showed that these cyclins do not share an overall sequence similarity (Additional file 1: Figure S1), because they belong to distinct types of cyclins. Phylogenetic analysis of these cyclins placed $\mathrm{CYC} 13$ to a distinct clade, to which the closest clade is the mitotic B-type cyclin clade (Fig. 1c).

To identify the CRK partner(s) of CYC13, we first carried out yeast two-hybrid assays to test its interaction with any of the eleven CRKs, and the results showed that CYC13 interacts with CRK2, CRK3, and CRK12 (Fig. 1d). Further, we carried out co-immunoprecipitation to test the in vivo interaction between $\mathrm{CYC} 13$ and the three CRKs. To this end, CYC13 was endogenously tagged with a PTP epitope in the trypanosome cells that express CRK2, CRK3, or CRK12 fused with a C-terminal triple HA epitope from their respective endogenous locus. Immunoprecipitation of CYC13-PTP was able to pull down CRK2-3HA, and immunoprecipitation of CRK2-3HA was able to pull down CYC13-PTP (Fig. 1e). However, immunoprecipitation of CYC13-PTP did not pull down CRK3-3HA and CRK12-3HA (Fig. 1f), and immunoprecipitation of CRK3-3HA or CRK12-3HA did not pull down CYC13-PTP (Additional file 1: Figure S2). These results identified CRK2 as the CDK partner of CYC13 in T. brucei.

\section{The CRK2-CYC13 complex is required for S-phase progression}

We carried out RNAi to investigate the function of the CRK2-CYC13 complex in the procyclic form of T. bru$c e i$. To assess the efficiency of RNAi, we epitope-tagged CYC13 and CRK2 from their respective endogenous locus in their respective RNAi cell line for western blotting. Induction of CYC13 RNAi and CRK2 RNAi each resulted in the reduction of their protein levels by $>90 \%$ after 1 day (Fig. 2a), indicating efficient depletion of the target protein by RNAi. Depletion of CYC13 and CRK2 each caused severe growth defects (Fig. 2b), suggesting that both proteins are essential for cell proliferation. We further analyzed the potential effects of CYC13 RNAi and CRK2 RNAi on cell cycle progression by counting the cells with different numbers of kinetoplasts and nuclei. T. brucei cells at different cell cycle stages can be readily distinguished by the numbers of kinetoplasts and nuclei. Cells at the G1 phase and early S phase of the 


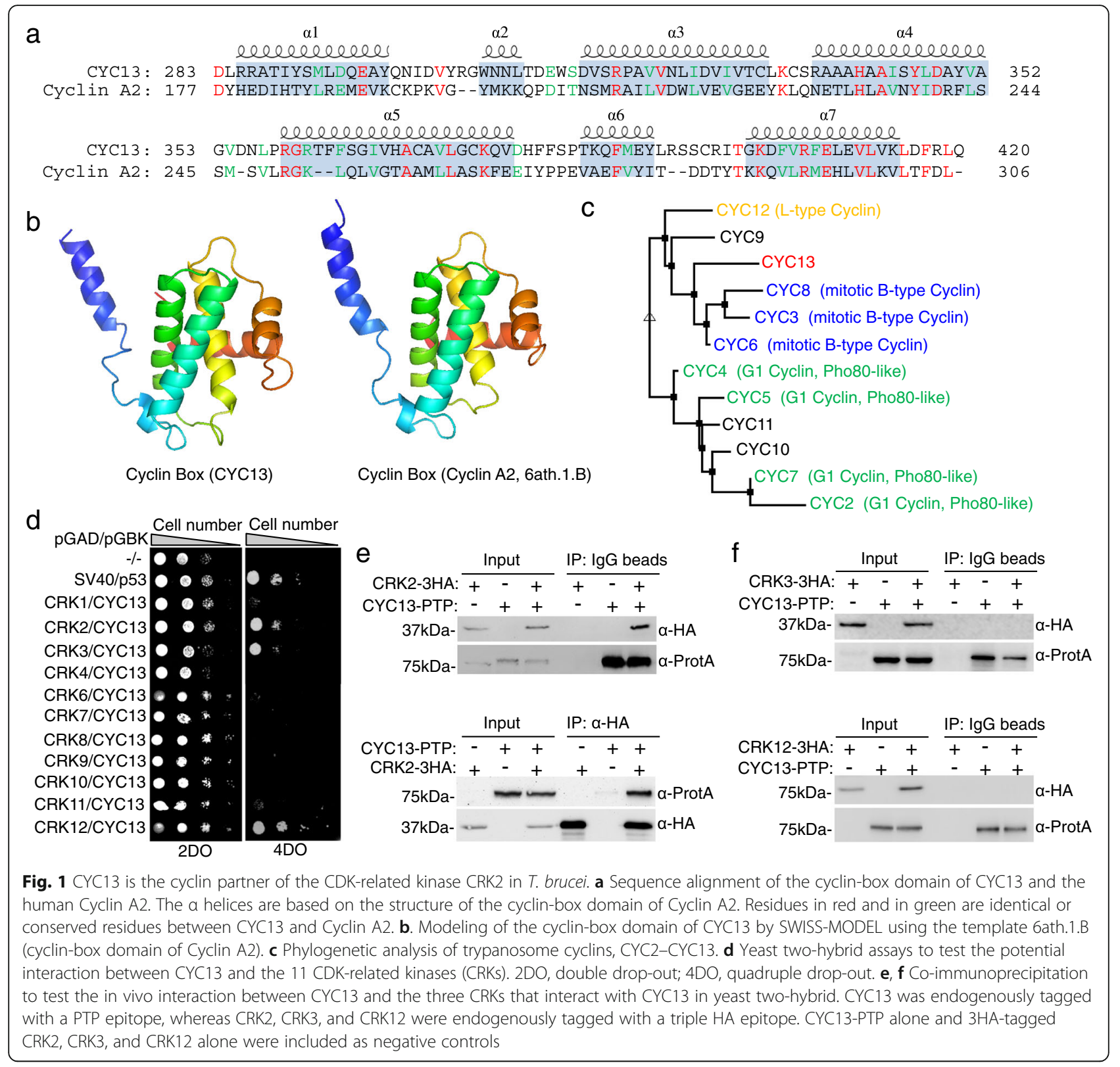

cell cycle contain one nucleus and one kinetoplast $(1 \mathrm{~N} 1 \mathrm{~K})$, cells at late $\mathrm{S}$ phase to early anaphase contain one nucleus and two kinetoplasts (1N2K), and cells at late anaphase to cytokinesis contain two nuclei and two kinetoplasts (2N2K). Knockdown of CYC13 caused an initial increase of $1 \mathrm{~N} 1 \mathrm{~K}$ cells at 24 $h$ and subsequently a decrease of $1 \mathrm{~N} 1 \mathrm{~K}$ and an emergence of two abnormal cell types, the $2 \mathrm{~N} 1 \mathrm{~K}$ cells $(\sim$ $18 \%$ ) and $0 \mathrm{~N} 1 \mathrm{~K}$ cells $(\sim 11 \%)$, at $48 \mathrm{~h}$ (Fig. $2 \mathrm{c})$. Unlike knockdown of CYC13, however, knockdown of CRK2 caused a gradual increase of $1 \mathrm{~N} 1 \mathrm{~K}$ cells from $\sim 76$ to $\sim 91 \%$ after RNAi induction for $48 \mathrm{~h}$, without a significant accumulation of abnormal cell types, the 2N1K cells and the 0N1K cells (Fig. 2c).
To further characterize the cell cycle defects of the two RNAi cell lines, flow cytometry was carried out. Knockdown of CYC13 caused a decrease of G1 cells by $35 \%$ and $\mathrm{G} 2 / \mathrm{M}$ cells by $13 \%$, and a corresponding increase of S-phase cells by $9 \%$, cells with DNA content greater than $4 \mathrm{C}$ by $27 \%$, and anucleate (sub-G1) cells by $12 \%$ at $48 \mathrm{~h}$ of RNAi (Fig. 2d). The emergence of cells with DNA content between $4 \mathrm{C}$ and $8 \mathrm{C}$ suggests that the bi-nucleated cells were undergoing the next round of DNA replication before cell division, and the accumulation of anucleate cells indicates aberrant cytokinesis of some of the bi-nucleated cells, which produced $2 \mathrm{~N} 1 \mathrm{~K}$ and $0 \mathrm{~N} 1 \mathrm{~K}$ cells. This profound effect of CYC13 knockdown on the cell cycle suggests that $\mathrm{CYC13}$ may play 


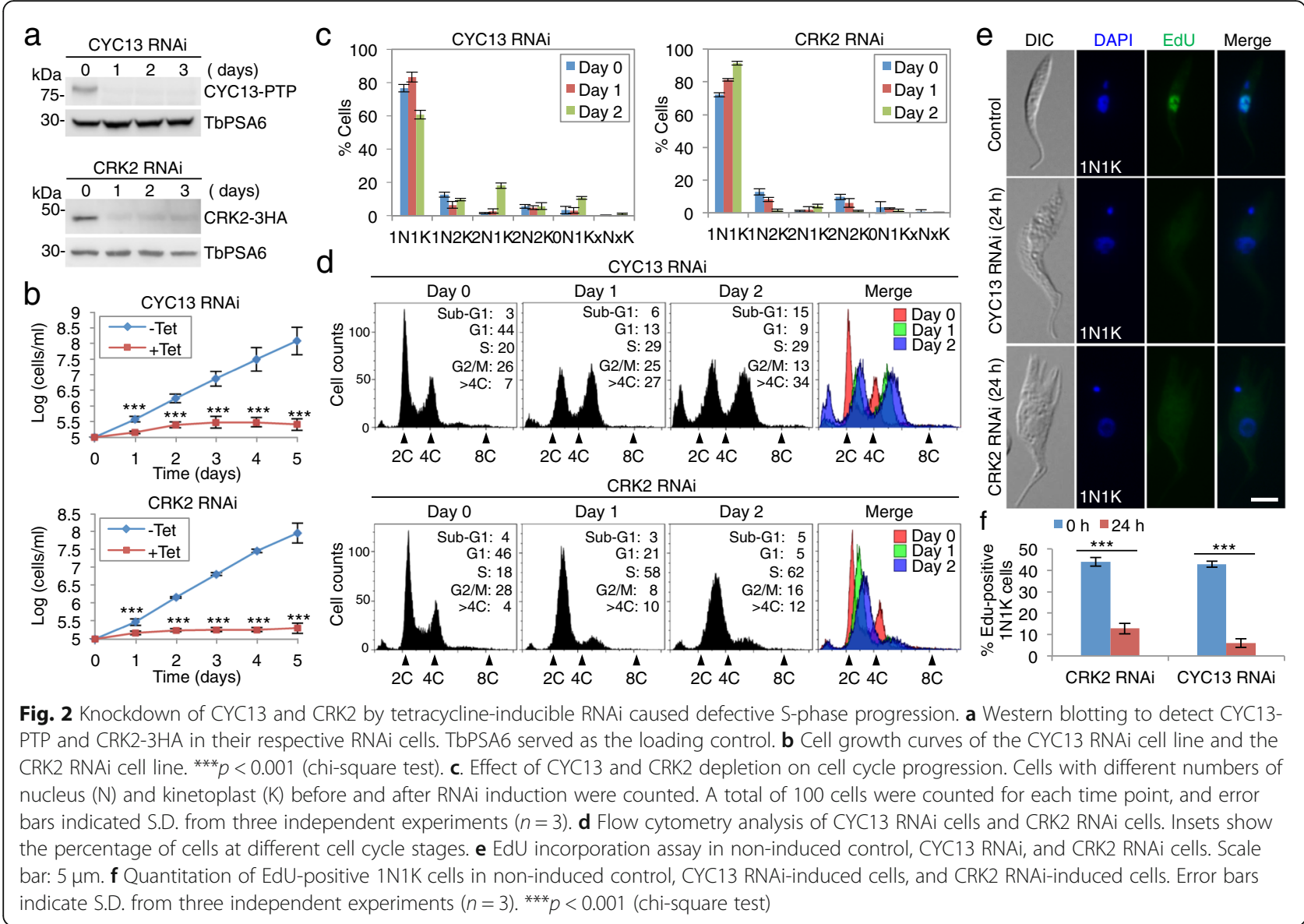

multiple roles at different cell cycle stages, including $\mathrm{S}$ phase. Knockdown of CRK2 caused a decrease of G1 cells by $41 \%$ and $\mathrm{G} 2 / \mathrm{M}$ cells by $12 \%$, and a corresponding increase of S-phase cells by $44 \%$ and cells with DNA content greater than $4 \mathrm{C}$ by $8 \%$, but no significant increase of anucleate cells (Fig. 2d). These results suggest that CRK2 plays a role in S-phase progression.

We next carried out EdU incorporation assay to examine the effect of CYC13 RNAi and CRK2 RNAi on DNA replication. Non-induced control and RNAi-induced cells were incubated with EdU, and the incorporation of EdU into DNA was monitored by fluorescence microscopy and by counting the number of EdU-positive $1 \mathrm{~N} 1 \mathrm{~K}$ cells (Fig. $2 \mathrm{e}, \mathrm{f}$ ). In the non-induced control cells, $\sim 43 \%$ of the $1 \mathrm{~N} 1 \mathrm{~K}$ cells were EdU-positive (Fig. 2e, f), indicating that these cells were undergoing DNA replication. In the RNAi-induced cells, $\sim 13 \%$ and $\sim 6 \%$ of the $1 \mathrm{~N} 1 \mathrm{~K}$ cells were EdU-positive for CRK2 RNAi and CYC13 RNAi, respectively (Fig. 2e, f), suggesting that the majority of the RNAi-induced cells failed to incorporate EdU into DNA. These results further demonstrated that knockdown of CYC13 and CRK2 impaired DNA replication.

Finally, we carried out immunofluorescence microscopy using KKT13 as an S-phase marker to examine the effect of CYC13 RNAi and CRK2 RNAi on S-phase progression. KKT13 is a kinetochore protein and is only expressed during the $\mathrm{S}$ phase of the cell cycle in $T$. brucei [30], and thus it can serve as an S-phase marker to distinguish the $1 \mathrm{~N} 1 \mathrm{~K}$ cells that are at either G1 phase or $\mathrm{S}$ phase. Immunostaining of KKT13 tagged with a Cterminal triple HA epitope from its endogenous locus was performed (Fig. 3), and the intensity of KKT13 fluorescence intensity was quantitated (Additional file 1: Figure S3), enabling us to distinguish between KKT13 fluorescence signal and the background signal for unambiguous counting of KKT13-positive cells. The results showed that the percentage of S-phase cells among the $1 \mathrm{~N} 1 \mathrm{~K}$ cell population was increased by $\sim 66 \%$ and $~ 70 \%$ after CYC13 knockdown and CRK2 knockdown, respectively (Fig. 3a-c). Since flow cytometry showed that the bi-nucleated cells of the CYC13 RNAi-induced cell population had entered the $\mathrm{S}$ phase of the next cell cycle (Fig. 2d), we examined KKT13 expression in the binucleated cells $(2 \mathrm{~N} 2 \mathrm{~K}$ cells from the control cell population and $2 \mathrm{~N} 2 \mathrm{~K}$ and $2 \mathrm{~N} 1 \mathrm{~K}$ cells from the CYC13 RNAiinduced cell population). We found that the KKT13positive bi-nucleated cells increased to $\sim 85 \%$ after CYC13 RNAi induction for $48 \mathrm{~h}$ (Fig. 3d, e), confirming 


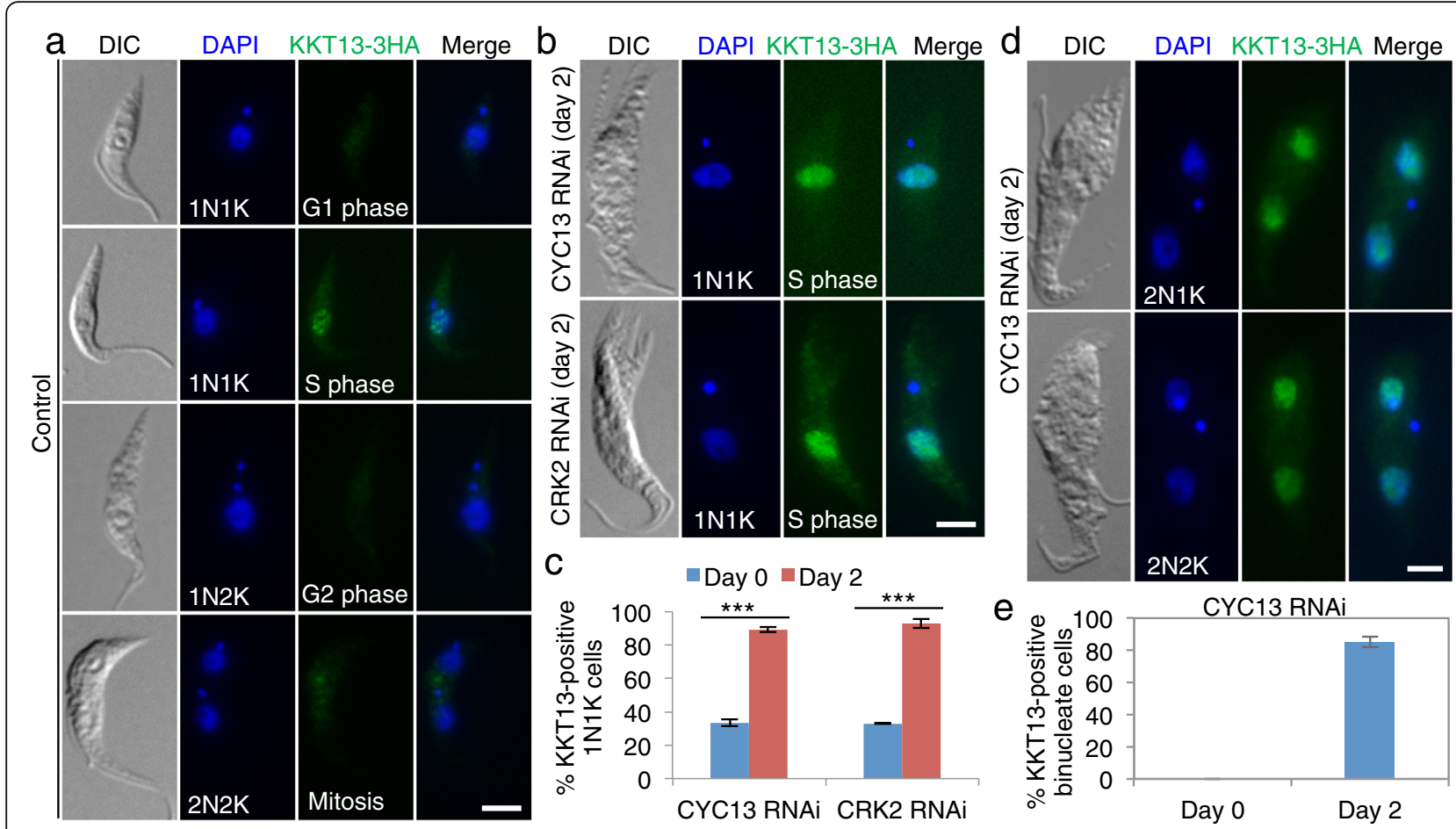

Fig. 3 Knockdown of CYC13 and CRK2 by tetracycline-inducible RNAi increased S-phase cells. a KKT13 as an S-phase marker in T. brucei. Shown is the localization of KKT13, which was tagged with a triple HA epitope from its endogenous locus in the CYC13 RNAi cell line and the CRK2 RNAi cell line, in non-induced control cells. Scale bar: $5 \mu \mathrm{m}$. b KKT13 expression in CYC13 RNAi-induced and CRK2 RNAi-induced cells. KKT13 was detected with FITC-conjugated anti-HA antibody. Scale bar: $5 \mu$ m. c Quantitation of KKT13-positive 1N1K cells before and after CYC13 RNAi and CRK2 RNAi induction. A total of 100 cells were counted for each cell line and each time point, and error bars indicated S.D. from three independent experiments $(n=3)$. ${ }^{* *} p<0.001$ (chi-square test). $\mathbf{d}$ KKT13-3HA was detected in the two nuclei of CYC13-depleted bi-nucleated (2N1K and 2N2K) cells. Scale bar: 5 m. e Quantitation of CYC13-positive bi-nucleate cells in non-induced control and CYC13 RNAi-induced cells. Error bars indicate S.D. from three independent experiments $(n=3)$

that the bi-nucleated cells were indeed arrested at the next round of $\mathrm{S}$ phase. All together, these results suggest that the CRK2-CYC13 complex plays an essential role in promoting $\mathrm{S}$-phase progression.

\section{The Cdc45-Mcm2-7-GINS complex subunit Mcm3 is a substrate of CRK2}

DNA replication in eukaryotes requires a cohort of DNA replication factors, including the CMG complex that functions as a replicative helicase to unwind the DNA duplex during DNA replication in the $S$ phase of the cell cycle [17]. Since the CRK2-CYC13 complex is required for DNA replication (Figs. 2 and 3), we asked whether CRK2 regulates the CMG complex by interacting and phosphorylating any of the CMG subunits. To test this possibility, we first carried out yeast two-hybrid assays to screen for the CRK2-interacting CMG subunit(s). CRK2 was fused with either the Gal4 DNAbinding domain (BD) or Gal4 activation domain (AD) and paired with each of the eleven CMG complex subunits that were fused with the $\mathrm{AD}$ or the $\mathrm{BD}$ (Fig. 4a). When fused with the BD, CRK2 interacted with Mcm3, Mcm5, Mcm6, and Sld5 (Fig. 4a, left panel), and when fused with the AD, CRK2 interacted with Mcm3, Sld5, and Psf3 (Fig. 4a, right panel). Collectively, both experiments identified Mcm3 and Sld5 as the interacting partners of CRK2. GST pull-down further confirmed that Mcm3 and Sld5 interacted with CRK2 in vitro (Fig. 4b).

To test whether Mcm3 and Sld5 are substrates of CRK2, in vitro kinase assay was performed with recombinant GST-fused proteins, GST-Mcm3, GST-Sld5, GST-CRK2, and GST-CYC13, all of which were expressed and purified from bacteria, using the non-radioactive thiophosphorylation method [31]. This method involves the use of the anti-ThioP antibody to detect thiophosphorylated proteins [31]. The in vitro kinase assay showed that CRK2 alone was able to phosphorylate $\mathrm{Mcm} 3$, and the addition of CYC13 increased the levels of phosphorylated Mcm3 (Fig. 4c), demonstrating that CYC13 promotes the kinase activity of CRK2. Further, to identify the phosphosites, mass spectrometry was carried out after in vitro kinase assay. A total of 1097 peptides, which were represented by 16 unique peptides and covered $\sim 76 \%$ of the entire protein, were identified for Sld5, and a total of 3997 peptides, which were represented by 91 unique peptides and covered $\sim 88 \%$ of the entire protein, were 


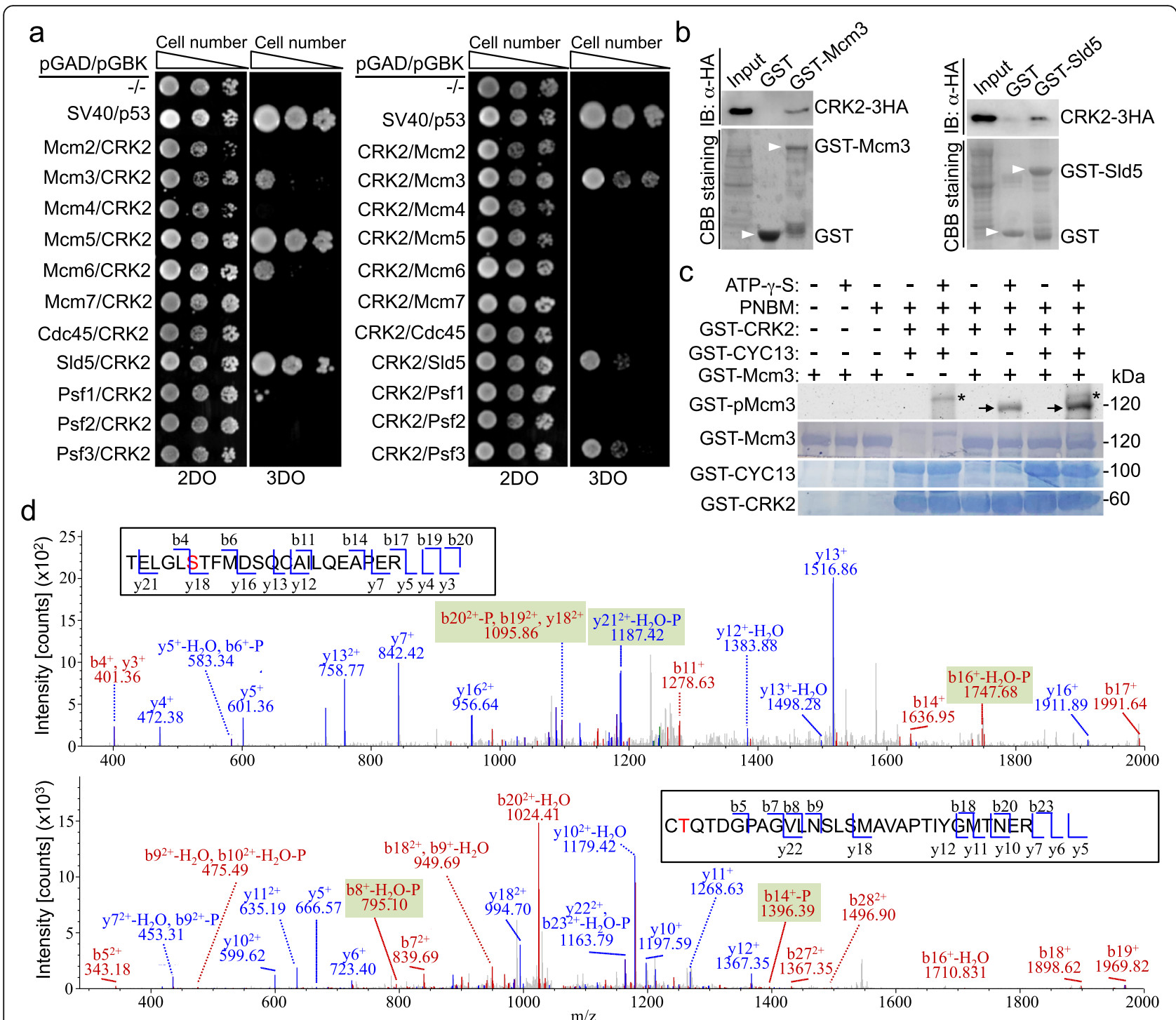

Fig. $4 \mathrm{Mcm} 3$ is a substrate of CRK2. a Yeast two-hybrid assays to test the potential interaction between CRK2 and the subunits of the CMG complex. 2DO, double drop-out; 3DO, triple drop-out. b GST pull-down to test the interaction between CRK2 and the CMG subunits Mcm3 and SId5. GST-Mcm3 and GST-SId5 were expressed and purified from bacteria, and CRK2-3HA was expressed in T. brucei. GST alone was used as the negative control. CBB, coomassie brilliant blue. $\mathbf{c}$ In vitro kinase assay of Mcm3 phosphorylation by CRK2 in the presence and absence of CYC13. GST-Mcm3, GST-CRK2, and GST-CYC13 were expressed and purified from E. coli. Arrows indicate phosphorylated GST-Mcm3 (GST-pMcm3), which was detected by the anti-ThioP antibody. GST-fused Mcm3, CRK2, and CYC13 were stained with coomassie brilliant blue. The asterisks indicate a non-specific band detected by the anti-ThioP antibody in the reactions to which purified GST-CYC13 was added. d MS/MS spectrum of Ser-213 (upper panel) and Thr-310 (lower panel) phosphopeptides identified from CRK2-phosphorylated GST-Mcm3. In vitro phosphorylated recombinant GST-Mcm3 was analyzed by LC-MS/MS. The phosphorylated Ser-213 and Thr-310 residues are shown in red

identified for Mcm3 (Additional file 1: Figure S4). Two phospho-peptides, which contained phosphorylated Ser213 and Thr-310, respectively (Fig. 4d), were identified for $\mathrm{Mcm} 3$, but not for Sld5, indicating that Mcm3 is a substrate of CRK2.

\section{Phosphorylation of Mcm3 at Thr-310 is essential for cell proliferation}

To test whether phosphorylation of Ser-213 and Thr310 in Mcm3 is essential for Mcm3 function, we carried out a functional complementation experiment (Fig. 5a). We first generated a Mcm3-3'UTR RNAi cell line by inserting an RNAi construct that targets the 3'UTR of Mcm3 gene into the rDNA locus. Subsequently, we inserted the PTP epitope-encoding sequence at the $5^{\prime}$ end of one allele of $\mathrm{Mcm} 3$ gene to express a PTP-Mcm3 fusion protein for monitoring RNAi efficiency. Finally, we replaced the other allele of Mcm3 gene with the sequence that encodes either wild-type or mutant Mcm3 proteins fused with a $\mathrm{C}$-terminal triple $\mathrm{HA}$ epitope 


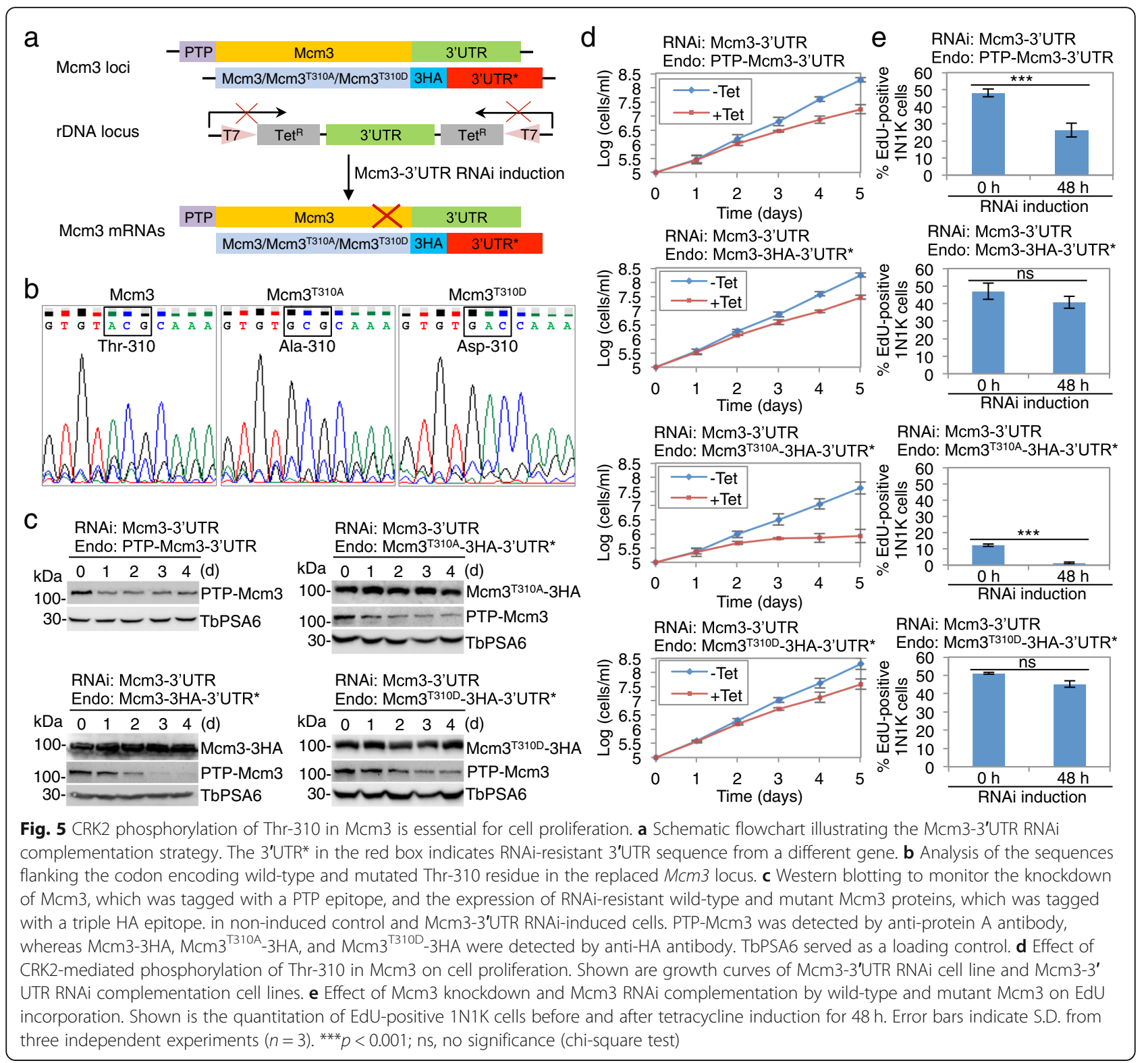

followed by a different $3^{\prime}$ UTR sequence that is resistant to Mcm3-3'UTR RNAi. When Mcm3-3'UTR RNAi is induced with tetracycline, the PTP-Mcm3 mRNA, but not the mRNA of 3HA-tagged wild-type and mutant Mcm3, will be knocked down (Fig. 5a), thus allowing to assess the effect of CRK2 phosphorylation on $\mathrm{Mcm} 3$ function. Epitope tagging of $\mathrm{Mcm} 3$ with either the triple HA epitope or the PTP epitope did not affect cell growth (Additional file 1: Figure S5). Using this approach, we attempted to generate the complementation cell lines for Ser-213 and Thr-310 and their respective mutants. However, we failed to replace $\mathrm{Mcm} 3$ with the Ser-213 phospho-deficient mutant $\left(\mathrm{Mcm}^{\mathrm{S} 213 \mathrm{~A}}\right)$ and the Ser-213 phospho-mimic mutant $\left(\mathrm{Mcm}^{\mathrm{S} 213 \mathrm{D}}\right)$ despite numerous tries, indicating that mutation of Ser-213 caused dominant-negative effects and killed cells. Thus, it was impossible to assess the contribution of Ser-213 phosphorylation to Mcm3 function using this approach.

Replacement of Mcm3 with the Thr-310 phosphodeficient mutant $\left(\mathrm{Mcm}^{\mathrm{T} 310 \mathrm{~A}}\right)$ and the Thr-310 phospho-mimic mutant $\left(\mathrm{Mcm}^{\mathrm{T} 310 \mathrm{D}}\right)$ was successful and was confirmed by sequencing of the PCR fragment amplified from the replaced Mcm3 allele (Fig. 5b). Western blotting showed that the N-terminal PTP-tagged Mcm3, but not the C-terminal 3HA-tagged $\mathrm{Mcm} 3$ and its mutants, was knocked down by Mcm3-3'UTR RNAi (Fig. 5c), confirming that RNAi of $\mathrm{Mcm} 3$ by targeting Mcm33'UTR was specific towards PTP-Mcm3. Induction of Mcm3 RNAi through targeting its 3'UTR caused partial reduction of $\mathrm{Mcm} 3$ protein level (Fig. 5c), and caused a 
moderate growth defect, resulting in a $\sim 11$-fold growth reduction after 5 days (Fig. $5 \mathrm{~d}$ ). EdU incorporation assay showed that induction of Mcm3-3'UTR RNAi for $48 \mathrm{~h}$ caused a reduction of the EdU-positive $1 \mathrm{~N} 1 \mathrm{~K}$ cells from $\sim 48$ to $\sim 26 \%$ (Fig. 5e). When one allele of Mcm3 was replaced with the RNAi-resistant wild-type $\mathrm{Mcm} 3$ and then RNAi was induced, PTP-Mcm3 was gradually knocked down and Mcm3-3HA was not affected (Fig. $5 \mathrm{c})$, but cell growth was only partly restored, resulting in a $\sim 6$-fold growth reduction after 5 days (Fig. 5 d). EdU incorporation assay showed that EdU-positive $1 \mathrm{~N} 1 \mathrm{~K}$ cells were reduced from $\sim 47$ to $\sim 41 \%$ after RNAi induction for $48 \mathrm{~h}$ (Fig. 5e). The lack of full rescue of the growth defect is likely due to the fact that only one allele of the Mcm3 gene expressed $\mathrm{Mcm} 3$ protein after RNAi induction and that Mcm3 protein level is so tightly controlled that a slight or moderate modulation of its level impacts cell growth. As a support of the notion that Mcm3 protein level is stringently regulated, ectopic overexpression of Mcm3 in the 29-13 cell line caused a severe growth defect, resulting in a $\sim 23$-fold growth reduction after 5 days (Additional file 1: Figure S6).

When one allele of Mcm3 was replaced with the RNAi-resistant $\mathrm{Mcm}^{\mathrm{T} 310 \mathrm{~A}}$ mutant, the cell line was not growing as well as other cell lines even without RNAi induction (Fig. 5d), suggesting that expression of $\mathrm{Mcm} 3^{\mathrm{T} 310 \mathrm{~A}}$ might cause dominant-negative effects but allowed slower cell proliferation. This notion was supported by the observed severe growth defects caused by ectopic overexpression of $\mathrm{Mcm}^{\mathrm{T} 310 \mathrm{~A}}$ in the $29-13$ cell line, which resulted in a $\sim 400$-fold growth reduction after 5 days (Figure S6). When Mcm3-3'UTR RNAi was induced, PTP-Mcm3 was gradually depleted and $\mathrm{Mcm}^{\mathrm{T} 310 \mathrm{~A}}-3 \mathrm{HA}$ was unaffected (Fig. 5c), but cell growth was inhibited, resulting in a $\sim 48$-fold growth reduction after 5 days (Fig. $5 \mathrm{~d}$ ), indicating that the $\mathrm{Mcm} 3^{\mathrm{T} 310 \mathrm{~A}}$ mutant failed to restore cell proliferation. EdU incorporation assay showed that without RNAi induction the EdU-positive $1 \mathrm{~N} 1 \mathrm{~K}$ cells only constituted $12 \%$ of the $1 \mathrm{~N} 1 \mathrm{~K}$ population, and after RNAi induction for $48 \mathrm{~h}$ EdU-positive $1 \mathrm{~N} 1 \mathrm{~K}$ cells were reduced to $\sim 1 \%$ of the total $1 \mathrm{~N} 1 \mathrm{~K}$ population (Fig. 5e).

When one allele of Mcm3 was replaced with the RNAi-resistant $\mathrm{Mcm}^{\mathrm{T} 310 \mathrm{D}}$ mutant and then RNAi was induced, PTP-Mcm3 was knocked down and $\mathrm{Mcm}^{\mathrm{T} 310 \mathrm{D}}$-3HA was unaffected (Fig. 5c), and cell growth was partially restored, resulting in a $\sim 5$-fold growth reduction after 5 days (Fig. $5 \mathrm{~d}$ ), similar to the wild-type Mcm3 complementation cell line (Fig. 5d). EdU incorporation assay showed that the EdU-positive $1 \mathrm{~N} 1 \mathrm{~K}$ cells were reduced from $\sim 51$ to $\sim 45 \%$ after RNAi induction for $48 \mathrm{~h}$ (Fig. 5e). When $\mathrm{Mcm}^{\mathrm{T}}{ }^{\mathrm{T} 10 \mathrm{D}}$ was ectopically overexpressed in the 29-13 cell line, it caused a moderate growth defect, resulting in a $\sim 14$-fold growth reduction after 5 days (Figure S6). Altogether, these results suggest that Thr-310 phosphorylation is essential for $\mathrm{Mcm} 3$ function in DNA replication.

\section{Phosphorylation of $\mathrm{Mcm} 3$ at Thr-310 is required for its interaction with SId5}

Having established the functional essentiality of $\mathrm{Mcm} 3$ Thr-310 phosphorylation (Fig. 5), we explored the underlying mechanisms by investigating the potential effect of Mcm3 phosphorylation on its interaction with other subunits of the CMG complex. We chose the subunit protein Mcm2 from the Mcm2-7 sub-complex, the subunit protein Sld5 from the GINS sub-complex, and Cdc45 to test their interaction with Mcm3 in CRK2 RNAi cells. We coexpressed Mcm3-3HA with Mcm2-PTP, PTP-Sld5, or Cdc45-PTP in cells harboring the CRK2 RNAi construct, and then performed co-immunoprecipitation to test the interactions in control and CRK2 RNAi cells. We found that immunoprecipitation of Mcm2-PTP was able to pull down Mcm3-3HA and the interaction between them was not affected by CRK2 knockdown (Fig. 6a). Similarly, coimmunoprecipitation of Cdc45-PTP and Mcm3-3HA was also unaffected by CRK2 knockdown (Fig. 6b). However, co-immunoprecipitaiton of PTP-Sld5 and Mcm3-3HA was impaired by CRK2 knockdown (Fig. 6c). CYC13 knockdown also affected the interaction between $\mathrm{Mcm} 3$ and Sld5 (Fig. 6d), albeit the effect was weaker than that caused by CRK2 knockdown, likely because CRK2 kinase activity was only partially reduced in the absence of $\mathrm{CYC13}$ (Fig. 4c). Further, to test whether phosphorylation of Thr-310 affects the interaction between $\mathrm{Mcm} 3$ and Sld5, we coexpressed PTP-Sld5 and 3HA-tagged wild-type Mcm3, phospho-deficient $\mathrm{Mcm} 3\left(\mathrm{Mcm} 3^{\mathrm{T} 310 \mathrm{~A}}\right)$, and phosphomimic $\mathrm{Mcm} 3\left(\mathrm{Mcm}^{\mathrm{T} 310 \mathrm{D}}\right)$, and then performed coimmunoprecipitation. The results showed that immunoprecipitation of Sld5 pulled down significantly less amounts of $\mathrm{Mcm} 3^{\mathrm{T} 310 \mathrm{~A}}$ protein, but significantly more amounts of $\mathrm{Mcm} 3^{\mathrm{T} 310 \mathrm{D}}$ protein than wild-type $\mathrm{Mcm} 3$ (Fig. 6e). Altogether, these results suggest that phosphorylation of Thr-310 in Mcm3 by CRK2 is required for $\mathrm{Mcm} 3$ interaction with the GINS subunit protein Sld5, but not Cdc45 and the Mcm2-7 complex subunit protein $\mathrm{Mcm} 2$.

\section{Discussion}

Tremendous efforts have been undertaken in the past to understand the functions of the expanded repertoire of cyclins and CRKs in T. brucei and to dissect the CRKregulated cellular pathways in T. brucei [32-46], but the S-phase cyclin-CRK pair had been overlooked, making the understanding of the CDK-mediated regulation of DNA replication in T. brucei impossible. T. brucei possesses a unique molecular composition of the DNA 


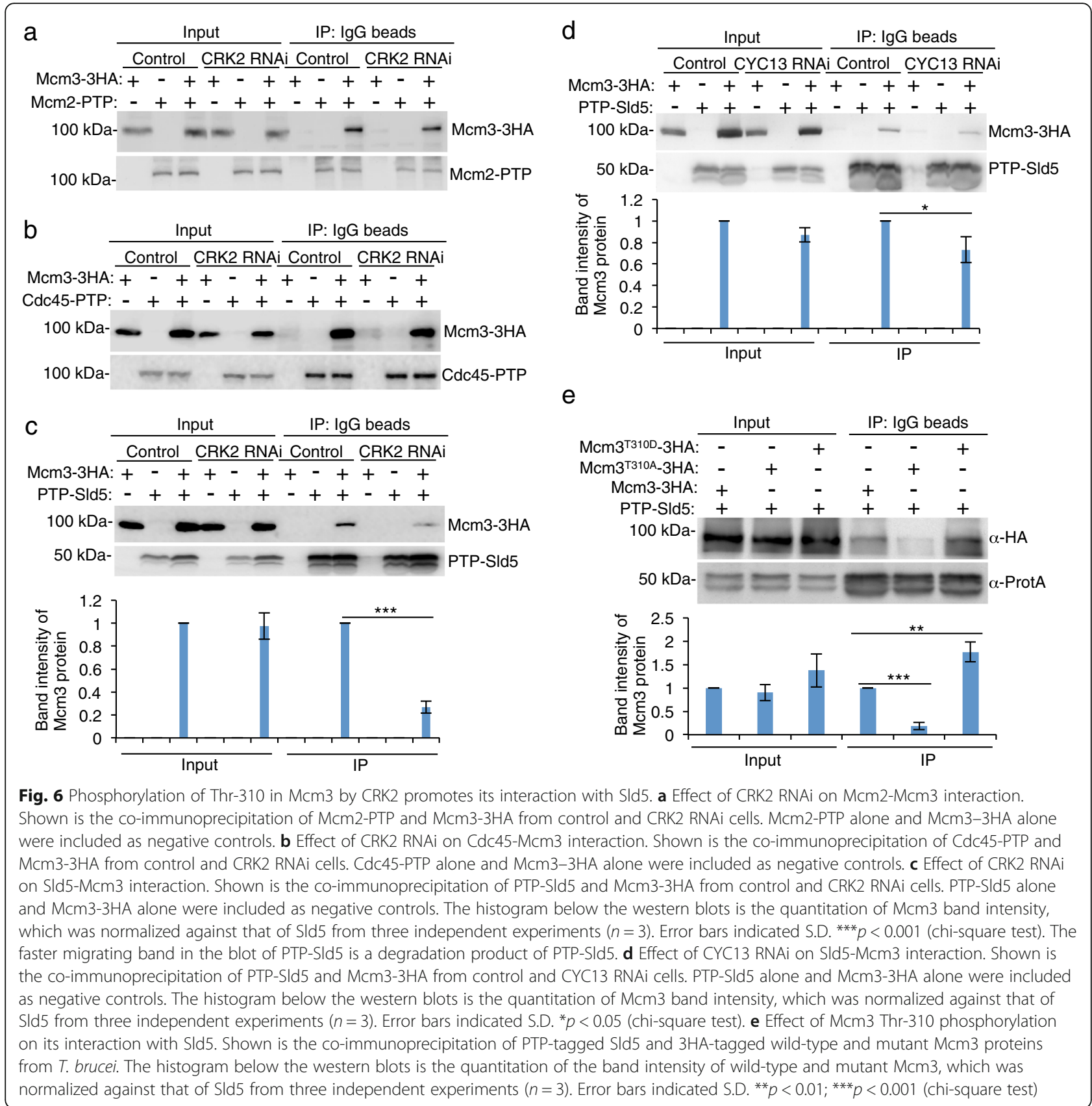

replication initiation machinery [22-24, 47] and lacks several key regulators of DNA replication [19, 48], suggesting distinct mechanisms and regulatory pathways for DNA replication. With the discovery of the CYC13CRK2 pair as a regulator of $\mathrm{S}$-phase progression in $T$. brucei, we are now able to delineate the signaling cascade controlling DNA replication in this early branching eukaryote, which might provide novel insights into the understanding of the evolution of the DNA replication machinery in eukaryotes.

Flow cytometry analysis of CRK2 RNAi cells detected a major S-phase peak (Fig. 2d), indicating the arrest of cells at $\mathrm{S}$ phase. Since RNAi induction was initiated in asynchronous cells containing $\sim 28 \%$ of the G2/M-phase cells (Fig. 2d), it suggests that these G2/M cells were able to divide, but the daughter cells were then arrested in the $S$ phase of the next cell cycle. Hence, knockdown of CRK2 did not inhibit G2/M progression and cytokinesis. Flow cytometry analysis of CYC13 knockdown cells, however, detected an S-phase peak, a post-G2/M peak, and a smaller sub-G1 peak (Fig. 2d). We interpreted these observations as follows. Upon CYC13 RNAi induction, G1 cells progressed and then were arrested in $S$ phase, producing uni-nucleated cells with DNA content 
greater than $2 \mathrm{C}$ but less than $4 \mathrm{C}$ (S-phase peak). However, G2/M cells re-initiated DNA replication without undergoing cytokinesis and then were arrested in the $\mathrm{S}$ phase of the next cell cycle, thus generating bi-nucleated cells with DNA content greater than 4C (post-G2/M peak). The anucleated cells (sub-G1 peak), together with the $2 \mathrm{~N} 1 \mathrm{~K}$ cells (Fig. 2c), were generated through aberrant division of some of the bi-nucleated cells. Thus, CYC13 plays one role through activating CRK2 to promote S-phase progression and another role through activation of an unidentified CRK to promote cytokinesis. This unidentified CRK might be among the remaining eight CRKs that showed no interaction with $\mathrm{CYC13}$ in yeast two-hybrid assays, but it may interact with $\mathrm{CYC} 13$ in vivo in trypanosomes. This subject is out of the scope of the current work and was not pursued further.

The identification of Mcm3 as a substrate of CRK2 (Fig. 4) and the finding that $\mathrm{Mcm} 3$ phosphorylation promotes Mcm3-Sld5 interaction (Fig. 6) provided the evidence to support the role of CRK2 in regulating S-phase progression. Mcm3 is an essential subunit of the CMG complex, the replicative helicase required for DNA replication initiation in eukaryotes [17]. T. brucei has a conserved CMG complex [22], but lacks the homolog of the Dbf4-dependent kinase (DDK), the major protein kinase responsible for Mcm2-7 phosphorylation [3]. DDK phosphorylates multiple $\mathrm{Mcm}$ proteins, such as $\mathrm{Mcm} 2$, Mcm4, and Mcm6 [4, 12, 49, 50], and phosphorylation of Mcm4 promotes the loading of Cdc45 to the Mcm27 complex [4]. CDK also phosphorylates multiple $\mathrm{Mcm}$ proteins, and phosphorylation of them plays distinct functions [51-55]. In human cell lines, Cdk1 phosphorylates $\mathrm{Mcm} 3$ at multiple sites and phosphorylation of Ser112 by Cdk1 promotes $\mathrm{Mcm} 3$ incorporation into the Mcm2-7 complex [53]. Phosphorylation of Thr-722 in Mcm3 by Cdk2 promotes its association with chromatin [56]. However, in T. brucei, phosphorylation of Mcm3 at Thr-310 likely does not affect the formation of the
Mcm2-Mcm3-Mcm5 sub-complex, but compromises the interaction between Mcm3 and Sld5 (Fig. 6), indicating the disruption of the interaction between $\mathrm{Mcm} 2-7$ and GINS within the CMG complex. It is possible that phosphorylation of different sites in $\mathrm{Mcm} 3$ might play distinct roles for $\mathrm{Mcm} 3$ function.

The CRK2 phosphosite on Mcm3, Thr-310, resides in the $\mathrm{N}$-terminal intrinsically disordered region that is 100 a.a. away from the Walker A motif of the $\mathrm{AAA}^{+}$ ATPase domain, indicating that this phosphorylation is unlikely to impact its ATPase activity. The Mcm4Mcm6-Mcm7 sub-complex has helicase activity, and the Mcm2-Mcm3-Mcm5 sub-complex may play regulatory roles [57]. In T. brucei, only Mcm4, but not other Mcm proteins, possesses in vitro helicase activity [22]. Within the CMG complex, Cdc45 interacts with Mcm2, and the GINS sub-complex interacts with $\mathrm{Mcm} 3$ and $\mathrm{Mcm} 5$ [58]. Therefore, our finding that Mcm3 interacts with the Sld5 subunit of the GINS sub-complex in T. brucei (Fig. 6) suggests that T. brucei CMG complex has similar subunit arrangements as in other eukaryotes. Based on the well-established order of loading of Mcm2-7, Cdc45, and GINS to the replication origins and the known protein-protein interactions among the CMG subunits $[22,59]$, we propose the following model to depict the order of assembly of the CMG complex and its regulation by CRK2 in T. brucei. Mcm2-7 is among the first set of DNA replication regulators to be loaded onto the replication origins. This is followed by the loading of Cdc45 onto the vicinity of $\mathrm{Mcm} 2$ and $\mathrm{Mcm} 5$ through a DDK-independent mechanism and, finally, after phosphorylation of Thr-310 in Mcm3 by CRK2, the GINS sub-complex is loaded onto the vicinity of $\mathrm{Mcm} 3$ and Mcm5 to form the CMG complex, thus leading to the initiation of DNA replication (Fig. 7). When CRK2 is knocked down, Mcm3 is not phosphorylated and the GINS sub-complex is not loaded onto the vicinity of Cdc45 and Mcm2-7; therefore, assembly of the CMG

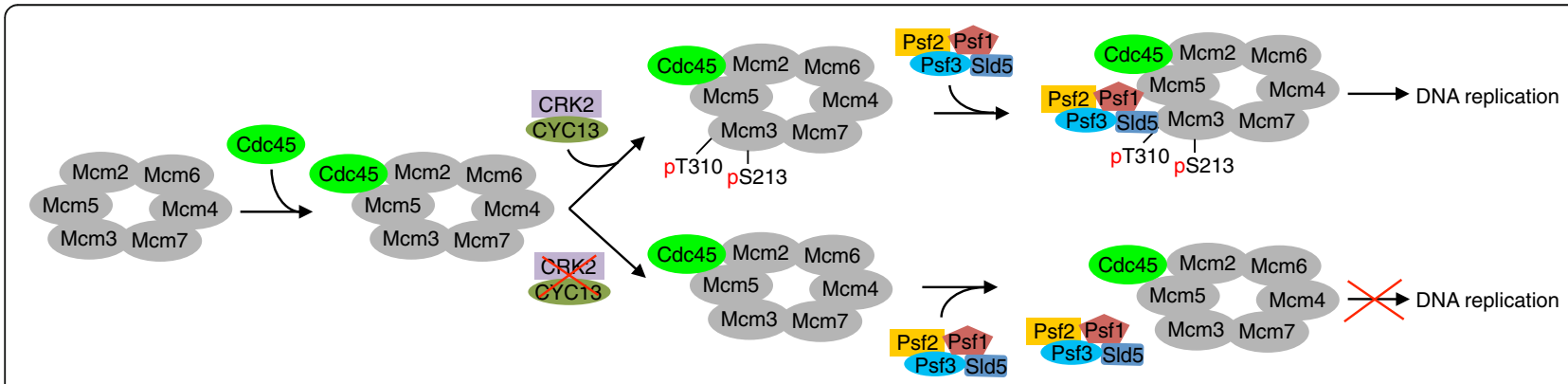

Fig. 7 Model of CRK2-mediated phosphorylation of Mcm3 and its effect on DNA replication. Prior to the initiation of DNA replication, the Mcm27 complex was first loaded onto chromosomes, followed by the loading of Cdc45, likely through interactions with $\mathrm{Mcm} 2 \mathrm{and} \mathrm{Mcm}$. Subsequently, CRK2 phosphorylates Mcm3 at Thr-310 and Ser-213, and phosphorylation of Thr-310 promotes the recruitment of the GINS complex to the Mcm2-7 complex, leading to the formation of the CMG complex and then the initiation of DNA replication. When CRK2 is deficient, the GINS complex is not recruited, and the CMG complex is not formed, thereby preventing the initiation of DNA replication 
complex is impaired and DNA replication is inhibited (Fig. 7). In this regard, CRK2 plays an essential role in DNA replication by facilitating the assembly of the CMG complex through promoting the interaction between Mcm3 and Sld5.

\section{Conclusions}

We have identified CYC13-CRK2 pair as an S-phase cyclin-CDK in the early branching trypanosomes, and we provided evidence to show that CYC13-CRK2 promotes DNA replication initiation and S-phase progression. CYC13-CRK2 phosphorylates Mcm3, a subunit of the Mcm2-7 complex, and this phosphorylation promotes the interaction of $\mathrm{Mcm} 3$ with Sld5, a subunit of the GINS complex, thereby facilitating the assembly of the Cdc45-Mcm2-7-GINS complex.

\section{Methods}

\section{Yeast two-hybrid assay}

Yeast two-hybrid assays were performed according to our published procedures [22]. Briefly, the full-length coding sequences of CYC13, the eleven CRKs, and the eleven subunits of the CMG complex were each cloned into the pGAD vector for expression of Gal4 activation domain fusion proteins (prey) or into the pGBK vector for expression of Gal4 DNA-binding domain fusion proteins (bait). Yeast strain AH109 (mating type a) and Y187 (mating type $\alpha$ ) were transformed with the prey and the bait plasmids, respectively. Yeast mating was carried out by mixing the AH109 and Y187 strains in YPDA medium and incubating on the SD-Leu-Trp plates at $30{ }^{\circ} \mathrm{C}$ for $24 \mathrm{~h}$. To test the interaction between prey and bait proteins, each combination stain was spotted in three 10-fold serial dilutions onto SD-Leu-Trp (2 drop-outs or 2DO), SD-Leu-Trp-His-Ade (3 drop-outs or 3DO), or SD-Leu-Trp-His-Ade (4 drop-outs or 4DO) plates, and then incubated at $30^{\circ} \mathrm{C}$ for up to 3 days. Growth of yeast on the 3DO and 4DO plates indicates interaction between the prey and the bait proteins. The empty vectors of pGAD and pGBK were used as the negative control, and the pair of SV40-p53 was used as the positive control.

\section{Trypanosome cell culture and tetracycline-inducible RNA interference}

The procyclic form of T. brucei strain Lister 427, which was used for epitope tagging of proteins, was cultured in SDM-79 medium supplemented with $10 \%$ heatinactivated fetal bovine serum (FBS, Sigma-Aldrich) at $27^{\circ} \mathrm{C}$. The procyclic 29-13 cell line [60], which expresses T7 RNA polymerase and tetracycline repressor for inducible RNAi and overexpression of genes, was cultured in SDM-79 supplemented with 10\% heat-

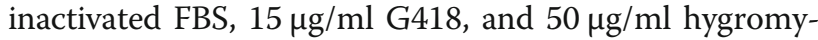
cin at $27^{\circ} \mathrm{C}$.

To generate the RNAi cell line for CYC13 and CRK2, the full-length coding sequence of CYC13 and a 417-bp DNA fragment (nucleotides 609-1025) from the coding region of CRK2 were each amplified by PCR and then cloned into the stem-loop RNAi vector, pSL [61], to generate the pSL-CYC13 and pSL-CRK2 constructs, respectively. The RNAi plasmid was linearized by NotI digestion and transfected into the 29-13 strain by electroporation. Transfectants were selected with $2.5 \mu \mathrm{g} / \mathrm{ml}$ phleomycin and cloned by limited dilution in a 96-well plate containing SDM-79 medium supplemented with 20\% heat-inactivated FBS and appropriate antibiotics. RNAi was induced by incubating the cells with $1.0 \mu \mathrm{g} / \mathrm{ml}$ tetracycline.

\section{Ectopic overexpression of $\mathrm{Mcm} 3$ and its mutants}

The full-length coding sequence of $\mathrm{Mcm} 3$ and its Thr310 phosphodeficient and phosphomimic mutants $\left(\mathrm{Mcm}^{\mathrm{T} 310 \mathrm{~A}}\right.$ and $\mathrm{Mcm} 3^{\mathrm{T} 310 \mathrm{D}}$ ) was cloned into the pLew100-3HA vector. The resulting plasmids were each transfected in the 29-13 strain by electroporation. Transfectants were selected $2.5 \mu \mathrm{g} / \mathrm{ml}$ phleomycin and cloned by limited dilution as described above. Cells were incubated with $1.0 \mu \mathrm{g} / \mathrm{ml}$ tetracycline to induce the overexpression of 3HA-tagged Mcm3 and its mutants.

\section{In situ epitope tagging of proteins}

Endogenous epitope tagging of proteins was performed using the one-step PCR-based epitope tagging method [62]. CRK2 and KKT13 were each tagged with a Cterminal triple HA epitope in the pSL-CRK2 cell line (both proteins) and the pSL-CYC13 cell line (KKT13 only), and transfectants were selected with $1 \mu \mathrm{g} / \mathrm{ml}$ puromycin and then cloned by limiting dilution. CYC13 was tagged with a C-terminal PTP epitope in the pSLCYC13 cell line, and transfectants were selected with $10 \mu \mathrm{g} / \mathrm{ml}$ blasticidin and then cloned by limiting dilution.

For co-immunoprecipitation between $\mathrm{CYC13}$ and CRK2, CRK3, or CRK12, CYC13 was tagged with a Cterminal PTP epitope in the Lister427 stain, and transfectants were selected with $40 \mu \mathrm{g} / \mathrm{ml} \mathrm{G} 418$ and cloned by limiting dilution. Subsequently, the clonal cell line was used for tagging of CRK2, CRK3, or CRK12 with a Cterminal triple $\mathrm{HA}$ epitope, and transfectants were selected with $1 \mu \mathrm{g} / \mathrm{ml}$ puromycin and then cloned by limiting dilution.

For co-immunoprecipitation between $\mathrm{Mcm} 3$ and Cdc45 and between Mcm3 and Sld5, Mcm3 was tagged with a C-terminal triple HA epitope in the pSL-CRK2 RNAi cell line and the pSL-CYC13 cell line, and transfectants were selected with $1 \mu \mathrm{g} / \mathrm{ml}$ puromycin and 
cloned by limiting dilution. Subsequently, the clonal cell lines were used for tagging of $\mathrm{Mcm} 2$ or Cdc45 with a Cterminal PTP epitope or Sld5 with an N-terminal PTP epitope, and transfectants were selected with $10 \mu \mathrm{g} / \mathrm{ml}$ blasticidin and then cloned by limiting dilution.

For co-immunoprecipitation of Sld5 and wild-type and mutant Mcm3, Sld5 was endogenously tagged with an Nterminal PTP tag in the cells harboring pLew100-Mcm33HA, pLew100-Mcm3 $3^{\text {T310A }}-3 \mathrm{HA}$, or pLew100$\mathrm{Mcm} 3^{\mathrm{T} 310 \mathrm{D}}-3 \mathrm{HA}$. Transfectants were selected with $1 \mu \mathrm{g} /$ $\mathrm{ml}$ puromycin and cloned by limiting dilution. Expression of Mcm3-3HA, Mcm3 $3^{\text {T310A }}-3 \mathrm{HA}$, and $\mathrm{Mcm}^{\mathrm{T} 310 \mathrm{D}}-3 \mathrm{HA}$ was induced with $0.1 \mu \mathrm{g} / \mathrm{ml}$ tetracycline for $6 \mathrm{~h}$, and then harvested for cell lysis and immunoprecipitation.

\section{Flow cytometry}

Flow cytometry was performed according to published procedures [43]. Cells were collected by centrifugation, washed with PBS, and then fixed with ethanol for $30 \mathrm{~min}$ at room temperature. Fixed cells were collected by centrifugation, washed once with PBS, and then suspended in PBS containing $10 \mu \mathrm{g} / \mathrm{ml}$ DNase-free RNase and $20 \mu \mathrm{g} / \mathrm{ml}$ propidium iodide. Cells were analyzed with a FACScan analytical flow cytometer (BD Biosciences) to quantitate the DNA content. The percentage of cells in different stages of the cell cycle was calculated by using the Kaluza Analysis software.

\section{In vitro GST pull-down}

The full-length coding sequences of $\mathrm{Mcm} 3$ and Sld5 were each cloned into the pGEX-4 T-3 vector (Clontech), and the resulting plasmids were transformed into the E. coli BL21 strain. Expression GST-fusion proteins was induced with $0.2 \mathrm{mM}$ IPTG for $4 \mathrm{~h}$ at room temperature and purified through binding to the Glutathione Sepharose 4B beads (GE HealthCare) according to the manufacturer's instructions. GST-Mcm3 and GST-Sld5 bound on the Glutathione Sepharose beads were incubated with cleared lysate of $T$. brucei cells expressing CRK2-3HA at room temperature for $30 \mathrm{~min}$. $T$. brucei cell lysate was prepared by lysing $10^{8}$ cells with 1 $\mathrm{ml}$ cell lysis buffer $(25 \mathrm{mM}$ Tris-Cl, pH 7.6, $100 \mathrm{mM}$ $\mathrm{NaCl}, 1 \mathrm{mM}$ DTT, $1 \% \mathrm{NP}-40$, and protease inhibitor cocktail) on ice for $30 \mathrm{~min}$ and then removing the insoluble pellets by centrifugation. $900 \mu \mathrm{l}$ of cell lysate was used for pull-down, and the remaining $100 \mu \mathrm{l}$ of cell lysate was set aside as the input sample. Beads were washed five times with the cell lysis buffer, and proteins were eluted by boiling the beads in $35 \mu \mathrm{l}$ of 1x SDS-PAGE sampling buffer for $5 \mathrm{~min}$. Eluted proteins $(25 \mu \mathrm{l})$ and the input sample $(15 \mu \mathrm{l})$ were fractionated by SDSPAGE, transferred onto a PVDF membrane, and immunoblotted with anti-HA antibody. Purified GST was used as the negative control.

\section{In vitro kinase assays}

The full-length coding sequences of CRK2 and CYC13 were each cloned into the pGEX-4 T-3 vector, and the resulting plasmids were transformed into E. coli BL21 strain. Recombinant GST-fused CRK2, CYC13, Mcm3, and Sld5 proteins were purified as described above. In vitro kinase assay was carried out using the method developed by the Kevin Shokat group, which uses a semisynthetic epitope for detection of thiophosphorylated kinase substrates [31]. In a 30- $\mu \mathrm{l}$ reaction setup, $10 \mu \mathrm{g}$ purified GST-Mcm3, GST-Sld5, GST-CRK2, and GSTCYC13 were mixed in the kinase assay buffer $(10 \mathrm{mM}$ HEPES, pH 7.6, $50 \mathrm{mM} \mathrm{NaCl}$, and $10 \mathrm{mM} \mathrm{MgCl}_{2}$ ) in the presence of $1 \mathrm{mM}$ ATP- $\gamma-S$ for $30 \mathrm{~min}$ at room temperature. Subsequently, $1.5 \mu \mathrm{l}$ of $50 \mathrm{mM}$ alkylating agent p-nitrobenzylmesylate (PNBM) was added into the kinase assay solution and incubated for $60 \mathrm{~min}$ at room temperature. Reaction was stopped by adding $1 \mathrm{x}$ SDS sampling buffer, and samples were separated by SDSPAGE, transferred onto a PVDF membrane, and blotted with the monoclonal anti-ThioP antibody, which recognizes the thiophosphate ester (1:5000 dilution, ThermoFisher). GST-fusion proteins on the membrane were stained with coomassie brilliant blue.

For mass spectrometry analysis of potentially phosphorylated GST-Mcm3 and GST-Sld5, in vitro kinase assay was performed using $1 \mathrm{mM}$ ATP and no PNBM was added to the reaction. GST-fusion proteins were separated on SDS-PAGE and stained with coomassie brilliant blue. The protein band corresponding to GSTMcm3 and GST-Sld5 was excised from the SDS-PAGE gel and analyzed by LC-MS/MS to identify phosphopeptides.

\section{In-gel tryptic digestion and LC-MS/MS analysis of protein band}

In-gel digestion of proteins was carried out as described previously [61]. Protein band was digested with trypsin (160 ng, Sigma-Aldrich) at $37^{\circ} \mathrm{C}$ for $4 \mathrm{~h}$, and peptides were extracted with $50 \mathrm{ml}$ of $50 \%$ acetonitrile, $5 \%$ formic acid. Extracted peptides were dried using SpeedVac, reconstituted in $2 \%$ acetonitrile with $0.1 \%$ formic acid, and then injected onto Thermo LTQ Orbitrap XL (Thermo-Fisher Scientific, Bremen, Germany). Samples in $2 \%(\mathrm{v} / \mathrm{v})$ acetonitrile and $0.1 \%(\mathrm{v} / \mathrm{v})$ formic acid were analyzed on an LTQ Orbitrap XL (Thermo-Fisher Scientific) interfaced with an Eksigent nano-LC 2D plus ChipLC system (Eksigent Technologies, Dublin, CA). Sample was loaded onto a ChromXP C18-CL trap column $(200 \mathrm{~mm}$ i.d. $\times 0.5 \mathrm{~mm}$ length) at a flow rate of 3 $\mathrm{ml} / \mathrm{min}$. Reversed-phase C18 chromatographic separation of peptides was carried on a on a ChromXP C18$\mathrm{CL}$ column $(75 \mathrm{~mm}$ i.d $\times 10 \mathrm{~cm}$ length) at $300 \mathrm{nl} / \mathrm{min}$. The LTQ Orbitrap was operated in the data-dependent 
mode to simultaneously measure full-scan MS spectra in the Orbitrap and the five most intense ions in the LTQ by CID, respectively. In each cycle, MS1 was acquired at target value $1 \mathrm{E} 6$ with resolution $\mathrm{R} 1 / 4 \quad 100,000$ (m/z 400) followed by top five MS2 scan at target value 3E4. The mass spectrometric setting is as follows: spray voltage was $1.6 \mathrm{KV}$, charge state screening and rejection of singly charged ion were enabled. Ion selection thresholds were 8000 for MS2, 35\% normalized collision energy, activation $\mathrm{Q}$ was 0.25 and dynamic exclusion was employed for $30 \mathrm{~s}$. Raw data files were processed and searched against the $T$. brucei database using the Mascot search engine. The search conditions used peptide tolerance of 10 p.p.m. and MS/MS tolerance of $0.8 \mathrm{Da}$ with the enzyme set as trypsin and two missed cleavages permitted.

\section{Mcm3 RNAi by targeting the $3^{\prime} U T R$ and functional complementation}

To generate the Mcm3-3'UTR RNAi cell line, a 497-bp DNA fragment from the 3'UTR of Mcm3 gene, which does not overlap with the downstream gene, was amplified by PCR and cloned into the pZJM vector [63]. The resulting plasmid, pZJM-Mcm3-3'UTR, was linearized by NotI digestion and transfected into the 29-13 strain by electroporation. Trasfectants were selected with $2.5 \mu \mathrm{g} / \mathrm{ml}$ phleomycin and cloned by limited dilution as described above. To monitor the efficiency of Mcm3-3'UTR RNAi, $\mathrm{Mcm} 3$ was tagged with an $\mathrm{N}$-terminal PTP epitope at one of its endogenous loci using PCR-based epitope tagging approach [62]. Transfectants were selected with $1 \mu \mathrm{g} / \mathrm{ml}$ puromycin, and cloned by limiting dilution as described above.

To generate the Mcm3 RNAi complementation cell lines, a 1920-bp DNA fragment (nucleotides 517-2436) of the coding sequence of $\mathrm{Mcm} 3, \mathrm{Mcm}^{\mathrm{T} 310 \mathrm{~A}}$, and $\mathrm{Mcm}^{\mathrm{T} 310 \mathrm{D}}$ was cloned into the pC-3HA-BSD vector, which contains the 3'UTR from TbRPA1 gene. The resulting plasmids were each linearized by restriction digestion with $X \mathrm{cmI}$ and electroporated into the cells containing the pZJM-Mcm3-3'UTR construct and expressing PTP-Mcm3 from one of its endogenous loci (see above). Transfectants were selected with $10 \mu \mathrm{g} / \mathrm{ml}$ blasticidin and then cloned by limited dilution as described above. Clonal cell lines were verified by sequencing of the PCR product amplified using the forward primer targeting Mcm3 sequence and the reverse primer targeting TbRPA1 3'UTR sequence, and by western blotting with anti-HA antibody to detect 3HA-tagged $\mathrm{Mcm} 3$ and its mutants expressed from one Mcm3 locus and with anti-protein A antibody to detect PTP-tagged Mcm3 expressed from the other Mcm3 locus (see Fig. 5a, b for details).

\section{Co-immunoprecipitation}

Co-immunoprecipitation was performed as described previously [64]. Briefly, $10^{8}$ cells were lysed in $1.0 \mathrm{ml}$ cell lysis buffer (25 mM Tris-Cl, pH 7.6, $100 \mathrm{mM} \mathrm{NaCl,} 1$ mM DTT, 1\% NP-40, and protease inhibitor cocktail) for $30 \mathrm{~min}$ on ice. Cell lysate was cleared by centrifugation, and cleared cell lysate $(0.9 \mathrm{ml})$ was incubated with $20 \mu \mathrm{l}$ IgG Sepharose 6 fast flow beads (GE Healthcare) for $1 \mathrm{~h}$ at $4{ }^{\circ} \mathrm{C}$. The remaining $100 \mu \mathrm{l}$ of cell lysate was set aside as the input sample. Proteins bound to the IgG beads were eluted by boiling the beads in $35 \mu \mathrm{l}$ of $1 \mathrm{x}$ SDS sampling buffer. Subsequently, $25 \mu \mathrm{l}$ of the eluted proteins and $15 \mu \mathrm{l}$ of the input sample were loaded onto a SDS-PAGE gel for protein separation. Proteins were transferred onto a PVDF membrane and immunoblotted with anti-HA antibody and anti-protein A antibody (Sigma-Aldrich). Intensity of the protein band was measured with the ImageJ software.

\section{EdU incorporation assay}

The Click-iT ${ }^{\mathrm{m}}$ EdU Alexa Fluor 488 imaging kit (ThermoFisher Scientific) was used to detect the incorporation of EdU into DNA. Cells were cultured in SDM-79 medium supplemented with $30 \mathrm{mM}$ EdU for $3 \mathrm{~h}$. Cells were collected by centrifugation, washed with PBS, adhered to glass coverslips, and fixed with $4 \%$ paraformaldehyde. Cells on the coverslips were used for EdU detection according to the manufacturer's instructions. Cells were visualized under a fluorescence microscope, and EdU-positive cells were counted.

\section{Immunofluorescence microscopy}

Cells were washed once with PBS, settled onto glass coverslips for $30 \mathrm{~min}$ at room temperature, and fixed with cold methanol for $30 \mathrm{~min}$ at $-20^{\circ} \mathrm{C}$. Cells were rehydrated with PBS and incubated with the blocking buffer (3\% BSA in PBS) for $1 \mathrm{~h}$ at room temperature. Cells were incubated with the FITC-conjugated anti-HA monoclonal antibody (1:400 dilution, Sigma Aldrich, Clone HA7) for $1 \mathrm{~h}$ at room temperature and washed three times with PBS. Coverslips were washed three times with PBS and mounted with DAPI-containing VectaShield mounting medium (Vector Labs). Immunostained cells were imaged with an inverted fluorescence microscope (Olympus IX71) equipped with a cooled CCD camera (model Orca-ER, Hamamatsu) and a PlanApo N $60 \times$ 1.42-NA lens. Images were acquired using the Slidebook 5 software and processed using the Adobe Photoshop software.

\section{Statistical analysis}

Statistical analysis was performed using the chi-square test in the Microsoft Excel software. Detailed $n$ values for each panel in the figures were stated in the corresponding figure legends. For immunofluorescence microscopy, images were randomly taken, and all cells in the image were counted. 


\section{Supplementary Information}

The online version contains supplementary material available at https://doi. org/10.1186/s12915-021-00961-1.

Additional file 1: Figure S1. Sequence alignment of the twelve cyclin proteins (CYC2-CYC13) in T. brucei. Figure S2. Co-immunoprecipitation to test the in vivo interaction between $\mathrm{CYC} 13$ and $\mathrm{CRK} 3$ and between CYC13 and CRK12. Figure S3. Quantification of KKT13 fluorescence intensity in non-induced control, CRK2 RNAi and CYC13 KPP1 RNAi cells. Figure S4. Coverage of the peptides detected by mass spectrometry in purified GST-SId5 and GST-Mcm3 after in vitro kinase assay with CRK2$\mathrm{CYC13}$. Figure S5. Effect of epitope tagging of $\mathrm{Mcm} 3$ on its function and cell growth. Figure S6. Ectopic overexpression of $\mathrm{Mcm} 3$ and its mutant in the 29-13 strain.

Additional file 2: Figure S7. Full western blots used for Fig. 1e, f. Figure S8. Full western blots used for Fig. 2. Figure S9. Full western blots used for Fig. 4b, c. Figure S10. Full western blots used for Fig. 5c. Figure S11. Full western blots used for Fig. 6a-e. Figure S12. Full western blots used for Figure S2. Figure S13. Full western blots used for Figure S5. Figure S14. Full western blots used for Figure S6.

\section{Acknowledgements}

The authors wish to thank Dr. Arthur Günzl of the University of Connecticut Health Center for providing the epitope-tagging plasmids and Dr. Li Li of the Clinical and Translational Proteomics Service Center of the University of Texas Health Science Center at Houston for assistance with mass spectrometry.

\section{Authors' contributions}

K.J.L. and Z.L. conceived and designed the project; K.J.L. performed experiments; K.J.L. and Z.L. analyzed data; Z.L. wrote the original manuscript; and K.J.L. and Z.L. reviewed and revised the manuscript. The authors read and approved the final manuscript.

\section{Funding}

This work was supported by the National Institutes of Health R01 grants Al118736 and Al101437 to Z. L and in part by the Clinical and Translational Proteomics Service Center at the University of Texas Health Science Center.

\section{Availability of data and materials}

All data reported in this paper are included in this published article and the supplementary information files. Full western blots were included as Additional file 2. All materials and cell lines reported in this paper are available upon request.

\section{Ethics approval and consent to participate}

Not applicable

\section{Consent for publication}

Not applicable

\section{Competing interests}

The authors declare that there is no conflict of interest.

Received: 6 August 2020 Accepted: 15 January 2021 Published online: 11 February 2021

\section{References}

1. Blow JJ, Dutta A. Preventing re-replication of chromosomal DNA. Nat Rev Mol Cell Biol. 2005;6(6):476-86.

2. Remus D, Diffley JF. Eukaryotic DNA replication control: lock and load, then fire. Curr Opin Cell Biol. 2009;21(6):771-7.

3. Labib K. How do Cdc7 and cyclin-dependent kinases trigger the initiation of chromosome replication in eukaryotic cells? Genes Dev. 2010;24(12):120819.

4. Sheu YJ, Stillman B. Cdc7-Dbf4 phosphorylates MCM proteins via a docking site-mediated mechanism to promote $S$ phase progression. Mol Cell. 2006; 24(1):101-13.

5. Tanaka S, Umemori T, Hirai K, Muramatsu S, Kamimura Y, Araki H. CDKdependent phosphorylation of SId2 and SId3 initiates DNA replication in budding yeast. Nature. 2007:445(7125):328-32.
6. Zegerman P, Diffley JF. Phosphorylation of SId2 and SId3 by cyclindependent kinases promotes DNA replication in budding yeast. Nature. 2007:445(7125):281-5.

7. Araki H, Leem SH, Phongdara A, Sugino A. Dpb11, which interacts with DNA polymerase II (epsilon) in Saccharomyces cerevisiae, has a dual role in S-phase progression and at a cell cycle checkpoint. Proc Natl Acad Sci U S A. 1995;92(25):11791-5.

8. Kanemaki M, Sanchez-Diaz A, Gambus A, Labib K. Functional proteomic identification of DNA replication proteins by induced proteolysis in vivo. Nature. 2003;423(6941):720-4.

9. Kubota $Y$, Takase $Y$, Komori $Y$, Hashimoto $Y$, Arata T, Kamimura Y, Araki H, Takisawa $H$. A novel ring-like complex of Xenopus proteins essential for the initiation of DNA replication. Genes Dev. 2003:17(9):1141-52.

10. Takayama Y, Kamimura Y, Okawa M, Muramatsu S, Sugino A, Araki H. GINS, a novel multiprotein complex required for chromosomal DNA replication in budding yeast. Genes Dev. 2003;17(9):1153-65.

11. Muramatsu S, Hirai K, Tak YS, Kamimura Y, Araki H. CDK-dependent complex formation between replication proteins Dpb11, Sld2, Pol (epsilon\}, and GINS in budding yeast. Genes Dev. 2010; 24(6):602-612

12. Masai H, Taniyama C, Ogino K, Matsui E, Kakusho N, Matsumoto S, Kim JM, Ishii A, Tanaka T, Kobayashi T, et al. Phosphorylation of MCM4 by Cdc7 kinase facilitates its interaction with Cdc45 on the chromatin. J Biol Chem. 2006;281(51):39249-61.

13. Zou L, Stillman B. Assembly of a complex containing Cdc45p, replication protein A, and Mcm2p at replication origins controlled by S-phase cyclindependent kinases and Cdc7p-Dbf4p kinase. Mol Cell Biol. 2000;20(9):3086-96.

14. Calzada A, Hodgson B, Kanemaki M, Bueno A, Labib K. Molecular anatomy and regulation of a stable replisome at a paused eukaryotic DNA replication fork. Genes Dev. 2005;19(16):1905-19.

15. Gambus A, Jones RC, Sanchez-Diaz A, Kanemaki M, van Deursen F, Edmondson RD, Labib K. GINS maintains association of Cdc45 with MCM in replisome progression complexes at eukaryotic DNA replication forks. Nat Cell Biol. 2006;8(4):358-66.

16. Ilves I, Petojevic T, Pesavento JJ, Botchan MR. Activation of the MCM2-7 helicase by association with Cdc45 and GINS proteins. Mol Cell. 2010;37(2): 247-58.

17. Moyer SE, Lewis PW, Botchan MR. Isolation of the Cdc45/Mcm2-7/GINS (CMG) complex, a candidate for the eukaryotic DNA replication fork helicase. Proc Natl Acad Sci U S A. 2006;103(27):10236-41.

18. Burki $F$. The eukaryotic tree of life from a global phylogenomic perspective. Cold Spring Harb Perspect Biol. 2014;6(5):a016147.

19. Li Z. Regulation of the cell division cycle in Trypanosoma brucei. Eukaryot Cell. 2012:11(10):1180-90.

20. Tiengwe C, Marques CA, McCulloch R. Nuclear DNA replication initiation in kinetoplastid parasites: new insights into an ancient process. Trends Parasitol. 2014;30(1):27-36

21. Marques CA, McCulloch R. Conservation and variation in strategies for DNA replication of Kinetoplastid nuclear genomes. Curr Genomics. 2018;19(2):98109.

22. Dang HQ, Li Z. The Cdc45.Mcm2-7.GINS protein complex in trypanosomes regulates DNA replication and interacts with two Orc1-like proteins in the origin recognition complex. J Biol Chem. 2011;286(37):32424-35.

23. Tiengwe C, Marcello L, Farr H, Gadelha C, Burchmore R, Barry JD, Bell SD, McCulloch R. Identification of ORC1/CDC6-interacting factors in Trypanosoma brucei reveals critical features of origin recognition complex architecture. PLoS One. 2012;7(3):e32674.

24. Marques CA, Tiengwe C, Lemgruber L, Damasceno JD, Scott A, Paape D, Marcello L, McCulloch R. Diverged composition and regulation of the Trypanosoma brucei origin recognition complex that mediates DNA replication initiation. Nucleic Acids Res. 2016;44(10):4763-84.

25. Berriman M, Ghedin E, Hertz-Fowler C, Blandin G, Renauld H, Bartholomeu DC, Lennard NJ, Caler E, Hamlin NE, Haas B, et al. The genome of the African trypanosome Trypanosoma brucei. Science. 2005;309(5733):416-22.

26. Hammarton TC. Cell cycle regulation in Trypanosoma brucei. Mol Biochem Parasitol. 2007;153(1):1-8

27. Zukerberg LR, Patrick GN, Nikolic M, Humbert S, Wu CL, Lanier LM, Gertler FB, Vidal M, Van Etten RA, Tsai LH. Cables links Cdk5 and c-Abl and facilitates Cdk5 tyrosine phosphorylation, kinase upregulation, and neurite outgrowth. Neuron. 2000;26(3):633-46.

28. Biasini M, Bienert S, Waterhouse A, Arnold K, Studer G, Schmidt T, Kiefer F, Gallo Cassarino T, Bertoni M, Bordoli L, et al. SWISS-MODEL: modelling 
protein tertiary and quaternary structure using evolutionary information. Nucleic Acids Res. 2014;42(Web Server issue):W252-8.

29. Pagano M, Pepperkok R, Verde F, Ansorge W, Draetta G. Cyclin a is required at two points in the human cell cycle. EMBO J. 1992;11(3):961-71.

30. Akiyoshi B, Gull K. Discovery of unconventional kinetochores in kinetoplastids. Cell. 2014;156(6):1247-58

31. Allen JJ, Li M, Brinkworth CS, Paulson JL, Wang D, Hubner A, Chou WH, Davis RJ, Burlingame AL, Messing RO, et al. A semisynthetic epitope for kinase substrates. Nat Methods. 2007:4(6):511-6.

32. Mottram JC, Smith G. A family of trypanosome cdc2-related protein kinases. Gene. 1995;162(1):147-52.

33. Van Hellemond JJ, Neuville P, Schwarz RT, Matthews KR, Mottram JC. Isolation of Trypanosoma brucei CYC2 and CYC3 cyclin genes by rescue of a yeast $G(1)$ cyclin mutant. Functional characterization of CYC2. J Biol Chem. 2000;275(12):8315-23.

34. Li Z, Wang CC. A PHO80-like cyclin and a B-type cyclin control the cell cycle of the procyclic form of Trypanosoma brucei. J Biol Chem. 2003;278(23): 20652-8.

35. Hammarton TC, Clark J, Douglas F, Boshart M, Mottram JC. Stage-specific differences in cell cycle control in Trypanosoma brucei revealed by RNA interference of a mitotic cyclin. J Biol Chem. 2003:278(25):22877-86.

36. Hammarton TC, Engstler M, Mottram JC. The Trypanosoma brucei cyclin, CYC2, is required for cell cycle progression through G1 phase and for maintenance of procyclic form cell morphology. J Biol Chem. 2004;279(23):24757-64.

37. Tu X, Wang CC. The involvement of two cdc2-related kinases (CRKs) in Trypanosoma brucei cell cycle regulation and the distinctive stage-specific phenotypes caused by CRK3 depletion. J Biol Chem. 2004;279(19):20519-28.

38. Tu X, Wang CC. Coupling of posterior cytoskeletal morphogenesis to the G1/S transition in the Trypanosoma brucei cell cycle. Mol Biol Cell. 2005; 16(1):97-105.

39. Gourguechon S, Savich JM, Wang CC. The multiple roles of cyclin E1 in controlling cell cycle progression and cellular morphology of Trypanosoma brucei. J Mol Biol. 2007;368(4):939-50.

40. Gourguechon S, Wang CC. CRK9 contributes to regulation of mitosis and cytokinesis in the procyclic form of Trypanosoma brucei. BMC Cell Biol. 2009; 10:68.

41. Badjatia N, Ambrosio DL, Lee JH, Gunzl A. Trypanosome cdc2-related kinase 9 controls spliced leader RNA cap4 methylation and phosphorylation of RNA polymerase II subunit RPB1. Mol Cell Biol. 2013;33(10):1965-75.

42. Badjatia N, Park SH, Ambrosio DL, Kirkham JK, Gunzl A. Cyclin-dependent kinase CRK9, required for spliced leader trans splicing of pre-mRNA in trypanosomes, functions in a complex with a new L-type cyclin and a kinetoplastid-specific protein. PLoS Pathog. 2016;12(3):e1005498.

43. Liu Y, Hu H, Li Z. The cooperative roles of PHO80-like cyclins in regulating the G1/S transition and posterior cytoskeletal morphogenesis in Trypanosoma brucei. Mol Microbiol. 2013;90(1):130-46.

44. Monnerat S, Almeida Costa Cl, Forkert AC, Benz C, Hamilton A, Tetley L, Burchmore R, Novo C, Mottram JC, Hammarton TC. Identification and functional characterisation of CRK12:CYC9, a novel cyclin-dependent kinase (CDK)-Cyclin complex in Trypanosoma brucei. PLoS One. 2013;8(6):e67327.

45. Hu H, Gourguechon S, Wang CC, Li Z. The G1 Cyclin-dependent kinase CRK1 in Trypanosoma brucei regulates anterograde protein transport by phosphorylating the COPII subunit Sec31. J Biol Chem. 2016;291(30):1552739.

46. An T, Li Z. An orphan kinesin controls trypanosome morphology transitions by targeting FLAM3 to the flagellum. PLoS Pathog. 2018;14(5):e1007101.

47. Benmerzouga I, Concepcion-Acevedo J, Kim HS, Vandoros AV, Cross GA, Klingbeil MM, Li B. Trypanosoma brucei Orc1 is essential for nuclear DNA replication and affects both VSG silencing and VSG switching. Mol Microbiol. 2013;87(1):196-210.

48. Zhou Q, Hu H, Li Z. New insights into the molecular mechanisms of mitosis and cytokinesis in trypanosomes. Int Rev Cell Mol Biol. 2014;308:127-66.

49. Francis LI, Randell JC, Takara TJ, Uchima L, Bell SP. Incorporation into the prereplicative complex activates the Mcm2-7 helicase for Cdc7-Dbf4 phosphorylation. Genes Dev. 2009;23(5):643-54.

50. Lei M, Kawasaki Y, Young MR, Kihara M, Sugino A, Tye BK. Mcm2 is a target of regulation by Cdc7-Dbf4 during the initiation of DNA synthesis. Genes Dev. 1997;11(24):3365-74.

51. Ishimi Y, Komamura-Kohno Y. Phosphorylation of Mcm4 at specific sites by cyclin-dependent kinase leads to loss of Mcm4,6,7 helicase activity. J Bio Chem. 2001;276(37):34428-33.
52. Komamura-Kohno Y, Karasawa-Shimizu K, Saitoh T, Sato M, Hanaoka F, Tanaka S, Ishimi Y. Site-specific phosphorylation of MCM4 during the cell cycle in mammalian cells. FEBS J. 2006;273(6):1224-39.

53. Lin Dl, Aggarwal P, Diehl JA. Phosphorylation of MCM3 on Ser-112 regulates its incorporation into the MCM2-7 complex. Proc Natl Acad Sci U S A. 2008; 105(23):8079-84

54. Montagnoli A, Valsasina B, Brotherton D, Troiani S, Rainoldi S, Tenca P, Molinari A, Santocanale C. Identification of Mcm2 phosphorylation sites by S-phase-regulating kinases. J Biol Chem. 2006;281(15):10281-90.

55. Moses AM, Liku ME, Li JJ, Durbin R. Regulatory evolution in proteins by turnover and lineage-specific changes of cyclin-dependent kinase consensus sites. Proc Natl Acad Sci U S A. 2007;104(45):17713-8.

56. Li J, Deng M, Wei Q, Liu T, Tong X, Ye X. Phosphorylation of MCM3 protein by cyclin $\mathrm{E} /$ cyclin-dependent kinase 2 (Cdk2) regulates its function in cell cycle. J Biol Chem. 2011;286(46):39776-85.

57. Schwacha A, Bell SP. Interactions between two catalytically distinct MCM subgroups are essential for coordinated ATP hydrolysis and DNA replication. Mol Cell. 2001;8(5):1093-104.

58. Abid Ali F, Renault L, Gannon J, Gahlon HL, Kotecha A, Zhou JC, Rueda D, Costa A. Cryo-EM structures of the eukaryotic replicative helicase bound to a translocation substrate. Nat Commun. 2016;7:10708.

59. Ishimi Y. Regulation of MCM2-7 function. Genes Genet Syst. 2018;93(4):12533.

60. Wirtz E, Leal S, Ochatt C, Cross GA. A tightly regulated inducible expression system for conditional gene knock-outs and dominant-negative genetics in Trypanosoma brucei. Mol Biochem Parasitol. 1999;99(1):89-101.

61. Wei $Y$, Hu H, Lun ZR, Li Z. Centrin3 in trypanosomes maintains the stability of a flagellar inner-arm dynein for cell motility. Nat Commun. 2014;5:4060.

62. Shen S, Arhin GK, Ullu E, Tschudi C. In vivo epitope tagging of Trypanosoma brucei genes using a one step PCR-based strategy. Mol Biochem Parasitol. 2001;113(1):171-3.

63. Wang Z, Morris JC, Drew ME, Englund PT. Inhibition of Trypanosoma brucei gene expression by RNA interference using an integratable vector with opposing T7 promoters. J Biol Chem. 2000;275(51):40174-9.

64. Zhou Q, Hu H, Li Z. An EF-hand-containing protein in Trypanosoma brucei regulates cytokinesis initiation by maintaining the stability of the cytokinesis initiation factor CIF1. J Biol Chem. 2016:291:14395-409.

\section{Publisher's Note}

Springer Nature remains neutral with regard to jurisdictional claims in published maps and institutional affiliations.

Ready to submit your research? Choose BMC and benefit from:

- fast, convenient online submission

- thorough peer review by experienced researchers in your field

- rapid publication on acceptance

- support for research data, including large and complex data types

- gold Open Access which fosters wider collaboration and increased citations

- maximum visibility for your research: over $100 \mathrm{M}$ website views per year

At $\mathrm{BMC}$, research is always in progress.

Learn more biomedcentral.com/submission 